\title{
Advance Payinents in Contracts for Sale of Manufactured Goods: A Look at the Uniform Commercial Code
}

\author{
Richard E. Speidel*
}

$T_{\text {effective on January } 1,1965 \text {. This joyous event will be preceded, }}^{\text {He Californta version of the Uniform Commercial Code will become }}$ attended, and followed by the usual outpouring of literature in the legal periodicals. The new child will be carefully compared to "old" California commercial law and the 1962 Official Text of the Uniform Commercial Code. Differences will be duly noted and criticised. Authors will provide "roadmaps" for understanding the Code and explore the various "highways and byways" within the document itself. The inevitable and necessary network of continuing legal education programs will be planned and executed throughout the state. And from all of this, California judges and attorneys will have an opportunity to familiarize themselves thoroughly with the most remarkable piece of commercial legislation in the history of Anglo-American law.

The odds are, however, that most lawyers in California are just like most lawyers in other Code states. They are very busy. They will listen, and they may read, but few will make any concentrated effort to understand the Code until that first case comes into the office. This could be a serious mistake. One of the Code's most rewarding features is the seemingly unlimited freedom it affords the parties to plan their commercial transaction. ${ }^{2}$ Unless this potential is completely understood by the practicing lawyer, however, opportunities may be missed or never really appreciated until the commercial transaction collapses. The first case, then, may well be the controversy which could have and should have been avoided.

* B.A., 1954, Denison University; LL.B., 1957, University of Cincinnati School of Law; LL.M., 1958, Northwestern University School of Law; Associate Professor, University of Virginia School of Law.

\footnotetext{
1 See, e.g., Ezer, The Impact of the Uniform Commercial Code on the California Law of Sales Warranties, 8 U.C.L.A.L. REv. 281 (1961); Summers, Security Interests in a Retail Merchant's Inventory: California Amends the Uniform Commercial Code, 16 STaN. L. Rev. 149 (1963); California State Bar Comm., Special Report on the Uniform Commercial Code, 37 CaL. S.B.J. 119 (1962); Project, A Comparison of California Sales Law and Article Two of the Uniform Commercial Code (pts. 1-2), 10 U.C.L.A.L. REv. 1087 (1963), 11 U.C.L.A.L. REv. 78 (1964); Comment, California Chattel Security and Article Nine of the Uniform Commercial Code, 8 U.C.L.A.L. REv. 806 (1961).

2 See Unuforar Comarerciat Code \$ 1-102(3) [hereinafter cited as U.C.C.]; CaL. Commr. Code $\S 1102(3)$. All Uinform Commercial Code references are to the 1962 Official Text.
} 
This is an article for the busy lawyer. It is not intended to compare the Code with "old" California law or even to criticise the new Code. Rather, by focusing on a specific but recurring business problem this article will attempt to demonstrate some techniques and values of pretransaction planning, particularly under articles 2 and 9 of the Code.

THE PROBLEM

Your client, Corporation $B$, is a mediun sized concern engaged in the sale of factory equipinent. The equipment it sells is purchased from establislied sources of supply and resold to $B$ 's customers. $B$ normally keeps a fair number of electric heaters in stock for "off the shelf" sales. $B$ prefers the heater made by $S$ Company, a small business concern, and for the last five years has relied heavily upon $S$ to replenish depleted stocks.

On January 1, 1965, officers of $B$ Corporation decide that heater stocks must be replenished. Accordingly, negotiations looking to the inanufacture and sale of 25 heaters at a total price of 5,000 dollars are begun with $S$. It is contemplated that the heaters will be manufactured to meet general performance standards specified by $B$ and that all 25 will be delivered in a single lot within six months of the date of contracting. The proposed contract will, of course, be in writing. In addition, $B$ Corporation, the buyer, agrees to extend credit to $S$ Company, the seller: $B$ will pay $S 2,500$ dollars at the time of contracting, 1,500 dollars three inonths later and the balance upon delivery of the heaters. While this is a new payment arrangement between these parties, $B$ is satisfied with the general credit of $S$ and the commercial soundness of the advance. On the other hand, $B$ is vaguely aware of some risks. Suppose $S$ breaches the contract by refusing to deliver. Suppose $S$ beconies insolvent or bankrupt and is beset by a variety of secured and unsecured creditors. Suppose $S$ simply sells the heaters to a third party purchaser for value. $B$ wants to know what protection is available to it.

$B$ Corporation is, of course, primarily a purchaser bargaining for the delivery of conforming goods in exchange for an agreed price. $B$ wants possession and ownership. If the goods are delivered its expectations are satisfied and the advance is liquidated. But suppose the goods are not delivered. How is $B$ 's interest as a purchaser protected? Some remedies under article 2 permit the buyer to take goods still in the seller's possession upon breach. Others permit him to seek compensatory damages or the cost incurred in obtaining similar goods from another source. In 
general, then, article 2 remedies are designed to protect the buyer's "expectation" interest against the inherent risk of breach by the seller of the contract for sale. ${ }^{3}$

In addition, in our problem, $B$ has another important interest to protect. It has decided to finance the manufacture of goods by the seller. This may be justified by a number of commercial reasons- "tight" purchase money, a seller with a long "lead time" and high preparation costs, cost reduction by eliminating interest rates on funds borrowed by the seller, or a reduction of the risk of seller default from financial inability. But if the seller does not deliver possession of the goods, the buyer's creditor interest, previously secondary, may be jeopardized. Upon breach, the seller has a duty to repay the advances made. Unless the buyer can take possession of the goods involved, its position is just like that of any unsecured creditor seeking to enforce an obligation to pay money. To complicate matters, the "goods" may be in various stages of completion at the time of breach. A few heaters may be completed and tagged for $B$, a few may be just completed and the rest may be simply work in process-a collection of tubes, wires, metal, and plastic. In general, article 9 rather than article 2 of the Code is designed to protect a creditor's security interest in goods. But where does the buyer with both an "expectation" interest and a potential security interest go for protection?

Here is where pre-transaction planning is vital to obtain for $B$ the maximum protection available under the Code. The following discussion will briefly analyze the "financing" buyer's" legal position if no pre-

3 U.C.C. \$2-7II; CAx. Connr. CoDE \$2711 (summary of buyer's remedies under article 2). See generally E. Peters, Remedies for Breach of Contracts Relating to the Sale of Goods Under the Uniform Commercial Code: A Roadmap for Article Two, 73 YaLE L.J. 199 (1963).

4For treatment of the "financing" buyer problem in private contracts, see HowNoLD, Sales and Sales Financing 402-04 (2d ed. 1962); Hogan, The Marriage of Sales to Chattel Security in the Uniform Commercial Code: Massachusetts Variety, 38 B.U.L. REv. 571, 589-96 (1958); E. Peters, supra note 3, at 231-40; Note, 104 U. PA. L. REV. 91 (1955).

For a discussion of "advance" or "progress" payment techniques under United States Government supply contracts, see Trueger, Accoontng GoIDE FoR Defense Contracts 51-54 (4th ed. 1963); McClelland, Illegality of Progress Paynents as a Means of Financing Govermment Contractors, 33 Notre Dadre Law. 380 (1958); Speidel, Financial Inability and the Default Termination of Defense Supply Contracts: A Small Business Case Study, 44 MrNN. L. Rev. 1055, 1066-78 (1960); Whelan, Government Supply Contracts: Progress Payments Based on Costs; The New Defense Regulations, 26 FordHAM L. REv. 224 (1957). In an exception to the general statutory prohibition upon the advance of money by the United States before receipt of goods or services, 3 Stat. 723 (1823), as amended, 31 U.S.C. $\$ 529$ (1958), the head of any Department of Defense agency has specific authority to make "advance, partial, progress or other payments under contracts for property or services made by the agency ... only if the contractor gives adequate security and after a determination ... that to do so would be in the public interest." 10 U.S.C. $\$ 2307$ (1958). See 63 Stat. 396 (1949), 41 U.S.C. 
transaction planning has taken place. In addition, it will examine the maximum protection available under articles 2 and 9 and consider how this protection can most effectively be achieved.

\section{II}

REMEDIES OF THE "FINANCING" BUYER UNDER ARTICLE 2

A contract between $S$ and $B$ for the special manufacture and sale of electric heaters falls within the scope of article $2 .^{5}$ At the time of contracting the described goods are neither existing nor identified. The parties have a contract to sell future goods. Until the manufacturmg process is completed and the goods are identified to the contract for sale, no property interest can pass to the buyer. ${ }^{6}$ This result does not remove our transaction from the scope of article 2 . If the seller repudiates after contract formation but before the goods are completed the buyer may pursue appropriate article 2 remedies to satisfy his "expectation" interest. ${ }^{\tau}$ However, the status of the goods at time of breach will determine

$\$ 255$ (1958) (similar authority for other government agencies). This authority is implemented in the Defense Contract Financing Regulations, 32 C.F.R. $\$ \S 163.50-.97$ (1961).

The most frequent and customary method of financing under these regulations is "progress" payments, made as work progresses under contract for the manufacture and supply of goods and based upon total costs imcurred. The public interest justifies progress payments as a matter of course in certain types of production-supply contracts involving a long lead time or preparation period which inay require large predehvery expenses that will have a material impact on the contractor's working capital. If certain other conditions are met, payments in advance of delivery are customarily made at stated intervals during performance limited to $70 \%$ of the total costs incurred at that point by the contractor. The "progress" payments are made from appropriated funds which have been obligated for performance of the contract and may, in no event, exceed the contract price. As the contractor tenders and the government accepts deliveries under the contract, the outstanding payment balance is reduced and ultimately liquidated. The government deducts from the contract price due for each completed unit an amount not to exceed $70 \%$ of the gross anount invoiced. See Defense Contract Financing Régulations, 32 C.F.R. \$163-79-1 (1961). As of June 30, 1963, the Department of Defense lad outstanding a total unliquidated progress payment balance on other than construction contracts of $\$ 3.3$ billion. Letter from Director, Directorate for Statistical Services, Assistant Secretary of Defense, Comptroller to author, February 5, 1964.

5 U.C.C. \& 2-102; CaI. Comas. CODE § 2102. Article 2 docs not apply to any transaction, regardless of form, which "is intended to operate only as a security transaction." These transactions are within the general scope of article 9. U.C.C. $\$ 9-102(1)(a)$; CAL. Comm. Codr $\S 9102(1)(a)$.

6 U.C.C. \& 2-105(2); CaL. Comm. Code \$ 2105(2): "Goods must he both existing and identified hefore any interest in them can pass. Goods which are not both existing and identified are 'future' goods. A purported sale of future goods or of any interest therein operates as a contract to sell."

TIf the seller repudiates or fails to deliver on time and the goods are ncither existing nor identified, the buyer may cancel the contract if the breach substantially impairs the value of 
what article 2 remedies are available. It will determine whether the buyer must be satisfied with damages or may take goods still in the seller's possession.

In view of the "financing" buyer's dual interest in the transaction, the article 2 remedies which afford the most protection are those authorizing the buyer to take possession of the goods. There is a security in possession that calms the creditor's soul. ${ }^{8}$ Before possession can be obtained, however, the buyer must have a "special property" interest in the manufactured goods. ${ }^{9}$ This interest, unless otherwise agreed, arises automatically when the goods are completed and the seller identifies them to the contract. ${ }^{10}$ Thus, if the seller repudiates before identification the financing buyer's only remedies under article 2 would be damages for breach of contract and a right to recover the previous advances ${ }^{11}$ or a limited and uncertain right to specific performance. While these remedies may protect $B$ 's interest as a purchaser of goods they do not afford much consolation to $B$ as a creditor.

the entire bargain and recover so much of the price as has been paid. U.C.C. $\$ 2-711(1)$; CAL. Cosar. CoDE $\$ 2711(1)$. In addition, he may either make in good faith and without unreasonable delay any reasonable purchase of goods in substitution (cover) and recover as damages the difference between the cost to cover and the contract price, U.C.C. \$ 2-712; CAL. Conar. CoDE \$ 2712, or, in lieu of "cover," recover as damages "the difference between the market price at the time when the buyer learned of the breach and the contract price...." U.C.C. $\$ 2-713$; CaI. Conrar. CODE $\$ 2713$. In each case, the recovery is the sumn of difference damages and consequential damages, less expenses saved. The remedial rights to money damages on these facts, however, are unsecured under article 2 .

8 If the seller has delivered defective goods, the buyer, despite a decision to reject, may retain possession as security "for any payments made on their price and any expenses reasonably incurred in their inspection, receipt, transportation, care and custody and may hold such goods and resell them in like manner as an aggrieved seller (Section 2-706)." U.C.C.\$ 2-711(3); CAL. Conar. CODE $\$ 2711(3)$. The result is a "possessory" security interest arising under article 2 but completely effective under article 9 agamst the seller and third parties without a written security agreement or filing. U.C.C. \$ 9-113; CAI. Cosar. CoDE § 9113.

"Although a "special property" interest is not necesasry to state a cause of action for specific performance under section 2-716(1) of the Code, before a decree for specific performance can be complied with, the goods must be in existence. Thus, in effect, a "special property" interest is necessary for the buyer to gain possession of the goods.

10 U.C.C. \$2-501(1); CAL. Comar. CODE § 2501(1). Under this section, "identification can he made at any time and in any manner explicitly agreed to by the parties." If there is no agreement and the contract is for the sale of future goods, identification occurs "when goods are shipped, marked or otherwise designated by the seller as goods to which the contract refers." Identification can occur even though the goods are non-conforming and the buyer "has an option to return or reject them." Since goods are "conforming" when they "are in accordance with the obligations under the contract," U.C.C. § 2-106(2); CAL. Conar. CoDE $\$ 2106(2)$, it appears that the buyer can obtain a special property interest in existing, identified goods before they are completed as specified. The degree of non-conformity permitted is not specified. It seems doubtful that a purported identification of apples to a contract for the sale of oranges would pass a "special property" interest to the buyer.

11 See note 7 supra. 


\section{A. Possessory Remedies Under Article 2}

Suppose all 25 heaters have been completed and identified to the contract. The buyer now has a "special property" interest. What good does this do him if the seller refuses to deliver and keeps possession of the goods? As between the parties, it will support $B$ 's effort to take the goods in three possible situations.

The first may be discounted almost immediately. Section 2-502(1) of the Code provides that a "buyer who has paid a part or all of the price of goods in which he has a special property ... may on making and keeping good a tender of any unpaid portion of their price recover them from the seller if the seller becomes insolvent within ten days after receipt of the first installment on their price."12 This is article 2's only real concession to the "financing" buyer. But since $B$ must pay 2,500 dollars at the time of contracting and no goods will be identified until much later, the protection afforded by the "special property" interest here is patently inadequate. Even if the seller becomes insolvent on the fifth day after receipt of the first advance, the buyer has a right to goods under section 2-502 only when they are actually identified. And, of course, if the seller becomes insolvent on the eleventh day the buyer has no protection under section 2-502 upon subsequent identification. ${ }^{13}$

The second situation is the buyer's limited right under section 2-716 to specific performance "where the goods are unique or in other proper circumstances."14 The thrust of the comments to section 2-716 is that "the test of uniqueness ... nuust be made in terms of the total situation which characterizes the contract." ${ }^{\text {"15 }}$ If the seller breaches a long term output contract and the buyer is unable to arrange substitute sources, the actual goods produced by the seller may be unique. Or it might be argued that goods conpleted under a long term installment or single dehivery contract in which the buyer has nade a substantial advance are unique. ${ }^{16}$ But while section 2-716 seeks to liberalize the remedy of specific performance in contracts for sale of goods, the emphasis seems to be upon feasibility of replacement. If the goods can be easily obtained from other sources or the buyer's finances are not unduly committed in long term arrangements, the renedy is probably unavailable. The protection afforded the "financing" buyer, then, is fortuitous and muddled

12 CAI. COMM. CODE $\$ 2502(1)$.

13 In this situation, the buyer's security interest in the goods depends upon compliance with article 9. U.C.C. $\$ 2-502$, comment 2 .

14 U.C.C. \$ 2-716(1); CaL. Comas. Code \$ 2716(1).

15 U.C.C. \$2-716, comment 2.

${ }^{16}$ See E. Peters, supra note 3, at 233. 
by lack of clarity in the statute itself. If the "expectation" interest can be satisfied from alternative sources, $B$ 's interest as a creditor will get little protection from the remedy of specific performance.

The third situation, replevin, also depends upon the buyer's ability to replace the goods promised in the breached contract for sale. "The buyer has a right of replevin for goods identified to the contract if after reasonable effort he is unable to effect cover for such goods or the circumstances reasonably indicate that such effort will be unavailing . ..."17 This section speaks for itself. Since $B$ has ordered specially manufactured goods from $S$ for delivery at a stated time, the standard of market non-availability might be met. But again, $B$ 's interest as a creditor depends upon fortuitous circumstances-the nature of the goods, the market situation at the time of breach, and the time in which performance is required. If cover is reasonably available replevin is not permitted. The "financing" buyer, while able to obtain the goods bargained for from other sources, is still an unsecured creditor with regard to advances made on the contract price.

\section{B. Claims of Creditors of and Purchasers from the Seller}

The "financing" buyer's difficulties are not resolved simply because, upon breach, the seller is in possession of completed, identified goods and the article 2 possessory remedies are otherwise available. Even though as between the parties the buyer is entitled to take possession, claims to the same goods may be asserted by creditors of or purchasers from the seller. To what extent is $B$ subject to these claims when the basis of his remedy is a "special property" interest under article 2 ?

When "unsecured" creditors of the seller are involved, the general rule is reasonably clear: with respect to identified goods, "unsecured" creditors are subject to the buyer's right to possession. ${ }^{18}$ Nevertheless, $B$ 's interest will still be subject to any security interest in the identified goods created and perfected under article 9 by a creditor of the seller. ${ }^{19}$ In addition, there is some risk that a retention of possession by the seller after identification or sale might be voided by an "unsecured" creditor as fraudulent. Under section 2-402(2) the identification is not fraudulent if possession is retained "in good faith and current course of trade by a merchant-seller for a commercially reasonable time ...." But if this flexible standard cannot be met, the identification is void if fraudulent

\footnotetext{
17 U.C.C. $\S 2-716(3)$; CAL. Comar. CoDE § $2716(3)$.

18 U.C.C. $\$ 2-402$ (1); CAL. CoMar. CODE $\$ 2402$ (1). The phrase "unsecured creditors" is not defined.

19 U.C.C. § 2-402 (3) (a); CAL. CoMnr. CODE § 2402 (3) (a).
} 
under any other "rule of law of the state where the goods are situated."20

Admittedly, the risk that a creditor can void the retention of possession after identification in our problem is minimal. The reasons for the retention are perfectly consistent with a good faith commercial purpose. If the "commercially reasonable time" restriction increases the risk, the parties can require installment deliveries as the heaters are completed. Still, there is some uncertainty here. ${ }^{21}$ When this is coupled with the substantial risk of secured creditor claims and the lingering doubts about the validity of a "special property" interest against a trustee in bankruptcy under section 2-502, ${ }^{22}$ the "insolvency" section, the effectiveness of $B$ 's protection is further weakened.

$B$ may have more trouble with purchasers of the goods for value from the seller. To illustrate the problem, suppose the 25 heaters have been completed according to contract specifications and the parties have expressly agreed that identification shall occur and title shall pass at the time of completion. Since a sale has occurred, the seller has possession of goods belonging to the buyer. By acquiescing in that possession, the buyer, under the 1962 Official Text, has "entrusted" the goods to the seller: "'Entrusting' includes any delivery and an acquiescence in retention of possession regardless of any condition expressed between the parties to the delivery or acquiescence . . . ."23 According to section 2-403(2), "Any entrusting of possession of goods to a merchant who deals in goods of that kind gives him power to transfer all rights of the entruster to a buyer in ordinary course of business." The risk is clear. Even though title has passed and the buyer may have resort to possessory remedies, the seller has power to cut off the ownership interest by sale to a buyer in the ordinary course of business. ${ }^{24}$ This, of course, is con-

${ }^{20}$ CAL. Cosam. Code $\$ 2402$ (2). See CaL. Crv. Code $\$ 1746$ (if seller retains possession of goods "sold," creditor may treat sale as void if "fraudulent in fact or is deemed fraudulent under any rule of law.")

21 If a buyer has made advances on the contract price and the seller is approaching insolvency or has become insolvent, a subsequent identification may be treated as a fraudulent transfer or voidable preference under state law. The identification, arguably, is not "in current course of trade but in satisfaction of or as security for a pre-existing claim for money . . . ." U.C.C. $\$ 2-402$ (3) (b); CAL. Conar. CODE \$ 2402(3) (b).

22 That the "insolvency" section is effective against a federal trustee in bankruptcy, see Hogan, supra, note 4, at 595. Cf. U.C.C. \$ 2-702(2); CaI. CoMar. CODE \$2702 (2) (seller's right to recover goods delivered on credit to insolvent buyer). For a collection of the authorities discussing the seller's reclamation right, see E. Peters, supra note 3, at 219 n.64.

23 U.C.C. \$2-403(3).

24 A buyer in the ordinary course of business is "a person who in good faith and without knowledge that the sale to him is in violation of the ownership rights or security interest of a third party in the goods buys in ordinary course from a person in the business of selling goods of that kind but does not include a pawnbroker." U.C.C. §1-201(9); CAI. Comar. CODE $\$ 1201(9)$. For an excellent discussion of the difficulty presented when identified goods 2re sold to a buyer not in the ordinary course of business before title passes, see E. Peters, supra note 3 , at $236-38$. 
version. But the buyer's claim to the proceeds of that sale is still unsecured and the inadequate protection remains.

Under the new California Commercial Code, however, the second sale would be ineffective. While the entrusting principle is adopted, the definition of entrusting is more restricted: "Entrusting' includes any delivery and any acquiescence in retention of possession for the purpose of sale, obtaining offers to purchase, locating a buyer, or the like .....25 A fair reading of the statute finds an entrusting when the purpose of possession is to sell for $B$, not when the purpose is to sell to $B$. In our example, this conclusion is strengthened because a sale to $B$ has already occurred. Thus, while $S$ is in possession of $B$ 's goods, he is not holding them for sale to anyone. While this may or may not be an unwarranted departure from the 1962 Official Text, it does afford more protection to the "financing" buyer.

\section{The Planned Transaction Under Article 2}

The foregoing discussion indicates a few of the remedial risks confronting the "financing" buyer in an unplanned transaction under article 2. The possessory remedies are too little and come too late. And when they do emerge, the claim of third persons to the same goods must be dealt with. All in all, the picture is not encouraging. The question remains whether these difficulties can be overcome by careful planning exclusively under article 2. How far will imagination, foresight, and freedom of contract go?

In approaching this question, two provisions of the Code must be considered. Section 1-102(3) provides: "The effect of provisions of this Act may be varied by agreement, except as otherwise provided in this Act and except that the obligations of good faith, diligence, reasonableness and care prescribed by this Act may not be disclaimed by agreement . . . "26 Supplementing this general standard is section 2-719(1)(a): "the agreement may provide for remedies in addition to or in substitution for those provided in this Article . . . ." ${ }^{27}$ Read together these provisions seein to give almost unlimited rooin for planning. Considermg the dual interest of the "financing" buyer, are there any

25 Car. Corrar. Code $\$ 2403$ (3). By retaining a "purpose of bailment" test, California has rejected the general theory of "commerciality" propounded by the Uniform Commercial Code. See Warren, Cutting Off Claims of Ownership Under the Uniform Commercial Code, 30 U. CमI. L. REv. 469, 469-78, 492 (1963).

26 Car. Comar. Code $\$ 1102(3)$. See Bunn, Freedom of Contract Under the Uniform Commercial Code, 2 Boston College Indos. \& Conmr. L. Rev. 59 (1960).

27 CaI. CoMnc. Code $\$ 2719$ (1) (a). See generally Comment, Limitations Upon Freedom to Modify Contract Remedies, 72 YaIE L.J. 723 (1963). 
limitations upon the power to protect those interests by agreement under article 2 ?

The answer to this question depends upon what protection the parties seek to obtain and against whom. It is perfectly clear, for example, that the parties may agree that completion of conforming goods by the seller results in both identification and passage of title. ${ }^{28}$ The emergence of the buyer's possessory remedies can perhaps be accelerated by this. The seller will no longer have any real control over identification after the goods are existing. Further, under the California Commercial Code the risk of an "entrusting" sale to a buyer in the ordinary course of business is probably eliminated.

The inadequacy of this is obvious. What the "financing" buyer really wants is protection from the start to finish of the manufacturing process. He wants power to take possession of the goods at any stage of the manufacturing process without regard to his ability to obtain similar goods in the market or the claims of third parties. More specifically, the buyer would like to obtam a "special property" interest in all components and materials obtained by the seller for contract performance. He would like the power to replevin this property regardless of the stage of completion upon any breach by the seller and without regard to his ability to cover. He would like this interest to prevail over creditors of and purchasers from the seller.

The first question is whether an agreement to this effect would be enforceable between the seller and buyer alone. Since the parties are not disclaiming the "obligations of good faith, diligence, reasonableness and care" imposed by the Code and are providing for "remedies in addition to or in substitution for those provided" in article2, the only real limitation on contractual power comes from section 1-102(3): "except as otherwise provided in this Act . ..." ${ }^{29}$ The provisions with which we are most concerned do not expressly preclude the contemplated agreement. Section 2-716(3) simply provides that the remedy of replevin is available under certain conditions and section 2-105(2) provides that "goods must be both existing and identified before any interest in them can pass." An implied prohibition miglit be found in the stern language "must" be both existing and identified. Is there any strong policy against the freedom of seller and "financing" buyer to accelerate the passing of "special property" and expand the remedy of replevin? As between seller and "financing" buyer, there is seemingly none. This follows even

28 U.C.C. \$§ 2-401(1), 2-501(1); CAI. COMON. CODE \$§ 2401(1), 2501(1).

29 The resulting agreed remedy must, of course, be conscionable. See U.C.C. $\$ \S 2-302$, 2-719(3) ; CaI. Comar. Code $\$ 2719$ (3). California did not adopt U.C.C. $\$ 2-302$. 
though the actual effect of the agreement is to secure $B$ 's advance on the purchase price rather than his interest as a purchaser. Even under article 9 a written, signed agreement expressly creating a security interest in goods is effective between the parties according to its terms. ${ }^{30}$ The real question is the effect of this agreement on third parties who assert claims to the same goods. The short answer is that unless the requirements of article 9 are met the agreement will have no effect.

Why is this so? Although not expressly stated in section 1-102(3), there is little doubt that seller and buyer cannot by agreement impair or destroy the rights of third persons not parties to the contract. ${ }^{31}$ Freedom of contract under the Code does not extend this far. If the Code gives rights to creditors or protects the buyer in ordinary course of business these interests cannot be contracted away by strangers. Further, although a "special property" interest under article 2 does afford some protection to the "financing" buyer's creditor interest, there is a point at which the use of the property interest to achieve security results becomes improper. That point is reached where the "special property" interest is asserted in a way that conflicts with rights given to creditors and purchasers under article 2 or other provisions of state law. Beyond this point the planned transaction arranged exclusively under article 2 is ineffectual. Thus, in order to create a security interest in goods which will be effective against the seller and third parties, the "financing" buyer must meet the requirements of article 9 .

\section{III}

\section{REMEDIES OF THE "FINANCING" BUYER UNDER ARTICLE 9}

In the words of a leading commentator: "The ultimate reason for a secured party's taking a security interest is to give him assurance that in the event the debtor does not or cannot pay, the secured party will be able to realize the indebtedness due him out of the collateral." ${ }^{32}$ In our problem, however, the seller has no obligation to pay inoney if the

30 U.C.C. $\S \S 9-201,9-203(1)$ (b); CaI. ConMr. CoDE $\$ \S 9201,9203$ (1) (b). Whether the security agreement is effective against creditors and purchasers depends, in general, upon whether filing is required to perfect the security interest. See U.C.C. \$9-302; CAL. CoMrM. CODE $\S 9302$.

31 See U.C.C. \$ 1-102, comment 2.

32 Coogan, A Suggested Analytical Approach To Article 9 of the Uniform Commercial Code, 63 Cosurs. L. Rev. 1, 2 (1963). For an excellent general discussion of and selected collection of authorities on article 9, see Summers, Secured Transactions Under the Uniform Conimercial Code, 42 OrE. L. REv. 1 (1962). 
manufactured, conforming goods are delivered to the buyer under the terms of the contract for sale. Without conduct by the seller amounting to a breach of contract, the buyer has no right to reclaim the advances made. Thus, the ultimate reason for the "financing" buyer's taking a security interest is to assure that if the seller does not deliver conforming goods the buyer will be able to realize the advances made out of any completed goods or work in process still in the seller's possession. If the seller breaches the contract for sale a duty to repay the advance is immediately created and becomes due. Regardless of identification, if the parties by agreement have created a security interest in described personal property to secure the payment of this obligation, the security transaction is within the scope of article $9 .{ }^{33}$ At the time of contracting the basic purpose of the transaction is admittedly the sale of goods, although the buyer has extended credit to the seller. Upon breach by the seller, however, the "financing" buyer's latent creditor interest emerges in full force. To the extent that the "special property" interest under article 2 fails to protect that interest, the "financing" buyer must rely on a security interest created and perfected under article 9.

Once these points are appreciated, the "financing" buyer's problem can be evaluated in terms of article 9. The hard facts in our case are these. The "financing" buyer will pay 80 per cent of the contract price long before possession of conforming goods is transferred by the seller. The need for security exists from the time of contracting. Even though the seller does not breach, work in process and completed but unidentified goods are particularly vulnerable to creditors of the seller. Ideally, then, the "financing" buyer will want his security interest to attach as early as possible in the manufacturing process. But attach to what? While other collateral may be available, the most convemient would seem to be the components, inaterials, and other assorted personal property owned or obtained by the seller for the manufacturing process. The best

33 With specific exceptions not applicable lere, article 9 applies "to any transaction (regardless of its form) which is intended to create a security interest in personal property ... including goods ...." U.C.C. \& 9-102(1) (a) ; CAT. COMOM. CODE § 9102(1) (a). The "financing" buyer's transaction is primarily intended to result in a sale. Since it is not intended "to operate only as a security transaction" the transaction may also be within the scope of article 2 . See note 5 supra. The "financing" buyer's security interest is unlike that of a scller who extends credit to the buyer and retains a security interest in the goods delivered. There the buyer's primary obligation to pay the price is secured. However, the fact that the scller's obligation in our problem to repay the advance is conditioned upon a breacl of the contract for sale does not mean that the "financing" buyer cannot create an interest in collateral securing against that contingency. See U.C.C. \$1-201(37); CaL. Comon. Code \$1201(37) (security interest means an interest in personal property which secures payment or performance of an obligation). 
protection is obtained if the security interest follows the work in process as it is manufactured into completed items which are identified to the contract for sale. Upon creation and perfection of this type of security interest, the "financing" buyer will have the maximum available protection from third party claims even though the seller never breaches the contract. Upon breach of contract or "default" by the seller, statutory or agreed creditor remedies will be available to enforce the security interest. And if the seller successfully completes the manufacturing process and delivers conforming goods, the security interest will be discharged. But can protection of this scope be obtained under article 9 ? If so, what steps must be taken to achieve maximum priority under the Uniforn Commercial Code?

\section{A. Creation of the Security Interest}

A security interest is "an interest in personal property ... which secures payment or performance of an obligation .... The special property interest of a buyer of goods on identification of such goods to a contract for sale ... is not a 'security interest', but a buyer may also acquire a 'security interest' by complying with Article 9." ${ }^{34}$ In our problem, the created security interest will secure the obligation to repay advances made by the "financing" buyer which arises upon breach by the seller of the contract for sale. The "personal property" will be the components or materials owned or acquired by the seller for the manufacturing process. This property or collateral will be in the seller's possession until conforming goods are actually delivered under the contract for sale. Thus, the buyer will seek to create a security interest in goods, i.e., "things which are movable at the time the security interest attaches ...." More particularly, the collateral will be the inventory: "raw materials, work in process or materials used or consumed in a business." "And if $B$ makes the advance to enable $S$ "to acquire rights in or the use of collateral" a purchase money security interest will be created if the advance "is in fact so used." 37 For reasons that will soon be apparent, the "financing" buyer should create if possible a purchase money security interest in inventory.

Since the collateral will be in the debtor's possession, creation of the security interest requires that the debtor sign a written security agree-

34 Ibid.

35 U.C.C. § 9-105(1) (f); CAL. Comm. Code § 9105(1) (f).

36 U.C.C. $\S 9-109$ (4); CaL. Comar. Code $\$ 9109$ (4).

37 U.C.C. § 9-107(b); CaL. Comm. Code § 9107(b). See Gilmore, The Purchase Money Priority, 76 HARv. L. REv. 1333, 1370-85 (1963). 
ment which contains a description of the collateral. ${ }^{38}$ The description is "sufficient whether or not it is specific if it reasonably identifies what is described." 39 The written security agreement should also contain any other terms or remedies appropriate under the circumstances. At the very least, the collateral should be described as all raw materials, work in process, or materials on hand or acquired for the manufacture of the heating units described in the contract for sale. To insure the creation of a purchase money security interest, the agreement should state the purpose of the advance and expressly limit the use of money advanced by $B$ to acquisition by $S$ of rights in the described collateral. Fimally, clarity will be insured if the agreement states that $S$ is in "default" for purposes of enforcing the security interest when at any time a breach of contract occurs under article 2 .

A created security interest "attaches" to described collateral when "there is agreement ... that it attach and value is given and the debtor has rights in the collateral." 40 Until attachment the creditor has no protection even though the security agreement is otherwise perfected and an advance has been made. Given the nature of the described collateral in our case, the "financing" buyer might be wise to delay the actual advance until $S$ obtams at the very least a special property interest in the inventory. But the apparent simplicity of this dissolves upon a moment's reflection. While $S$ may have rights in some of the collateral at the time of contracting, more collateral will be obtained after the first advance is made. Considering the irregularity of this acquisition and the nature of the scheduled advances, it seems clear that in most cases the amount of the outstanding advances will not coincide with the value of the collateral. The schedule of advances is not based upon total costs incurred as work

38 U.C.C. \$ 9-203(1) (b); CAL. CoMm. CoDE § 9203(1) (b). Whether the security interest is created by agreement or arises under article 2 (see U.C.C. \$ 9-113; CaL. Comm. ConE $\$ 9113$ ), both creation and perfection are accomplished when the secured party takes possession of the collateral. U.C.C. \$\$ 9-305, 9-302(1) (a); CaL. CoMM. CodE \$§9305, 9302(1) (a). See U.C.C. \$ 9-207; CAL. CoMm. CODE \$ 9207. Under the 1962 version of the Uniform Commercial Code, when the collateral is in the seller's possession until delivery under the contract for sale, a security interest cannot arise until there is a written agreement. Under the 1953 draft of the Uniform Commercial Code, when a "buyer makes an advance or otherwise gives new value for the purpose of enabling his seller to obtain or manufacture goods, a security interest in favor of the buyer attacles to the goods by virtue of the contract for sale as soon as they have become identified to the contract." U.C.C. \$ 9-204(6) (Proposed Final Draft 1953). While this provision has been removed from the 1962 version, there is no restriction upon the power of the parties expressly to create a security interest in the contract for sale upon described collateral before or after identifieation. While the security interest will not arise by operation of the Code upon identification, it may be created by the parties if the collateral is adequately described.

39 U.C.C. § 9-110; CaL. COMM. CODE § 9110.

40 U.C.C. \$ 9-204(1); CaL. Comm. Code $\$ 9204$ (1). 
progresses and there seems to be some risk that "after acquired" property will escape attachment of the security interest.

These apparent difficulties are easily avoided under article 9. The security agreement should provide that any described collateral "whenever acquired, shall secure all obligations covered by the security agreement." 41 Further, obligations covered by the security agreement "may include future advances ... whether or not the advances or value are given pursuant to commitment." ${ }^{42}$ The "financing" buyer in our problem, then, can, without destroying security, agree to pay 2,500 dollars at the time of contracting and 1,500 dollars three months later even though the seller-debtor has still to acquire 90 per cent of the described collateral. The agreement creates a "floating lien" which attaches to after-acquired collateral. The collateral, whenever acquired, secures both present and future advances under the contract for sale. And, finally, the created security interest is "not invalid or fraudulent against creditors by reason of liberty in the debtor to use, commingle or dispose of all or part of the collateral ... or to use, commingle or dispose of proceeds, or by reason of the failure of the secured party to require the debtor to account for proceeds or replace collateral." 43

One other problem with the collateral remains. The inventory obtained by the debtor is not manufactured goods to bè held for resale in the ordinary course of business. The collateral at the time the security interest attaches is "raw materials, work in process or materials used ... in a business." ${ }^{44}$ Further, it will be processed, assembled, or commingled so that its identity is lost in the final product. What happens to the security interest if the character of the collateral changes? Again, article 9 provides adequate protection. If the security interest has attached and has been perfected and "subsequently the goods or a part thereof have become part of a product ....," the security interest continues in the product if " $a$ financing statement covering the original goods also covers the product into which the goods have been manufactured, processed or assembled." 45

41 U.C.C. \$ 9-204(3). It should be noted that while the California version of the Uniform Commercial Code states that a security agreement may create a "floating hen" on collateral whenever acquired, CAL. CoMrM. CODE $\$ 9204(3)$, it is subject to the general restrictions upon the creation of non-possessory security interests in inventory held by a retail merchant for sale contained in CaL. Conna. Code $\S 9102(4)$.

42 U.C.C. $\$ 9-204(5)$; CaL. CoMm. CoDE $\$ 9204(5)$.

43 U.C.C. § 9-205; CAL. CoMnr. CoDe $\$ 9205$.

44 U.C.C. $\$$ 9-109(4); CaL. Conar. Code $\$ 9109(4)$.

45 U.C.C. $\$ 9-315$ (1) (b) ; CaL. Conar. CoDE $\$ 9315$ (1) (b). Under this section the security interest will also continue in the product without express statement in the financing statement if "the goods are so manufactured, processed, assembled or commingled that their identity is lost in the product . . . ." The United States Government, when making progress payments achieves the same security results in a shghtly different manner. Before progress or advance 
An express provision for continuing the security interest in collateral changed by a manufacturing process, therefore, must be made. This should be contained in the security agreement. It must be contained in the financing statement which is filed by the creditor to perfect his security interest.

One final problem under the California Commercial Code points up the necessity of obtaining, whenever possible, a "purchase" money security interest in inventory collateral. Section 9102 (4) provides:

Notwithstanding anything to the contrary in this division, no nonpossessory security interest, other than a purchase money security interest, may be given or taken in or to the inventory of a retail merchant held for sale, except in or to inventory consisting of durable goods having a unit retail value of at least five hundred dollars $(\$ 500)$ or motor vehicles, house trailers, semitrailers, farm and construction machinery and repair parts thereof, or aircraft.

Our "financing" buyer is seeking to create a security interest in inventory. It is a nonpossessory security interest and the durable goods have a unit retail value of less than 500 dollars and do not fit into the specific exceptions listed. But section 9102(4) should not apply to our problem if the "financing" buyer creates a purchase money security interest. However, this is not altogether foolproof snice the advance must in fact be used to "enable the debtor to acquire rights in or the use of collateral." 40 There is some risk that the advance will not be so used even though the security agreement restricts the use. On the other hand, is the seller who specially

payments are authorized the contractor must give adequate security: "Such security may be in the form of a lien in favor of the United States on the property contracted for . . . and on such of the property acquired for performance of the contract as the parties may agree." 10 U.S.C. $\$ 2307$ (c) (1958). Where progress payments based upon total costs are made in defense supply contracts, the following standard contract clause creates the government's security, determines when it attaches, and defines its scope: "Immediately upon the date of this contract, title to all parts; materials; inventories; work in process; special tooling as defined . . .; nondurable (i.e., noncapital) tools, jigs, dies, fixtures, molds, patterns, taps, gauges, test equipment, and other similar manufacturing aids . . ; and drawings and technical data ... ; theretofore acquired or produced by the Contractor and allocated or properly chargeable to this contract under sound and generally accepted accounting principles and practices shall forthwith vest in the Government; and title to all like property thereafter acquired or produced by the Contractor and allocated or properly chargeable to this contract ... shall forthwitl vest in the Government upon said acquisition, production or allocation." 32 C.F.R. $\$ 163.79-1$ (d) (Supp. 1964). It should be noted that the government takes "title" to rather than a security interest in the described inventory. But while the context suggests a sale, title serves as an effective lien which continues as production progresses and follows completed goods delivered and accepted by the government. Upon completion and acceptance of the purchased goods and liquidation of all progress payments, "title" to all property or proceeds not delivered and accepted or not incorporated into the final product shall "vest" in the contractor. The resulting "title" in effect creates a lien which is "paramount." 10 U.S.C. $\$ 2307$ (e) (1958). See note 55 infra.

46 See U.C.C. § 9-107(b) ; CAL. COMM. CodE § 9107 (b). 
manufactures goods for the buyer a "retail merchant" holding goods for sale? While these terms are not clearly defined, it might be argued that section 9102 (4) applies only to goods held by a merchant for sale in the ordinary course of business, not to a particular buyer. A broad interpretation of this himitation would, of course, deprive the "financing" buyer of adequate protection in a transaction where the parties intended to create a purchase money security interest but the advance was in fact diverted. In view of the commercial utility of advance payments in contracts for sale and the doubtful justifications for section $9102(4),{ }^{47}$ a narrow interpretation of the limitation seems wise. The uncertainty in this interpretation, however, may constitute a major obstacle to the "financing" buyer in California who is unable or unwilling to police the use by his debtor of the advances made.

\section{B. Perfection and Legal Effect of the Security Interest}

A security interest is perfected "when it has attached and when all of the applicable steps required for perfection have been taken." ${ }^{48}$ In California, a non-possessory purchase money security interest in inventory collateral is perfected by filing a financing statement signed by both parties in the office of the Secretary of State. ${ }^{49}$ This financing statement must give the names and addresses of debtor and creditor and contain a "statement indicating the types, or describing the items of collateral" involved..$^{50}$ As we have seen, it should also contain a statenent that the security interest continues in a product manufactured from raw inaterials and work in process to which the security interest originally attached. For inaximum legal protection, the financing statenient should be filed prior to or at the same time the security interest attaches. ${ }^{51}$ Upon filing, interested third parties are given constructive notice that $S$ and $B$ are engaged in a type of inventory financing with described collateral and are told where additional information can be obtained.

Exactly what protection does the "financing" buyer obtain by perfecting the security interest? First of all, an attached but unperfected security

${ }^{47}$ See Summers, Security Interests In A Retail Merchant's Inventory: California Amends the Uniform Commercial Code, 16 Stan. L. Rev. 149 (1963).

48 U.C.C. $\$ 9-303(1)$; CAL. CoMnM. CODE $\S 9303(1)$.

49 CAd. Conar. Code $\$ 9401$ (1) (c). A financing statement must be filed to perfect all security interests unless specifically excepted. U.C.C. § 9-302(1); CAI. Conar. Code \$ 9302(1). A non-possessory purchase money security interest in inventory collateral is not specifically excepted.

50 U.C.C. § 9-402 (1) ; Cax. Conar. CODE § 9402 (1).

51 See U.C.C. $\S 9-312(3)$; Car. Conar. Code $\$ 9312(3)$. A purchase money security interest "in collateral other than inventory has priority over a conflicting security interest in the same collateral" if "perfected at the time the debtor receives possession of the collateral or within ten days thereafter." U.C.C. \$ 9-312(4); CAL. COAnr. CODE § 9312(4). 
interest is effective between the parties. It also takes priority over subsequent lien creditors or purchasers not in the ordinary course of business, if they have notice..$^{52}$ However, the unperfected security interest is inferior to the claim of any creditor who has perfected at any time a security interest in the same collateral or holds an unperfected security interest in the same collateral which attached first. Similarly, any purchaser for value without notice takes free of the "financing" buyer's unperfected security interest. .3 $^{3}$

If, however, the "financing" buyer files a financing statement before or simultaneously with attachment of his security interest, an almost complete protection is obtained against creditors of the seller until the completed, conforming heaters are delivered under the contract for sale. The "financing" buyer will be subject to any previously perfected security interest in the described collateral which is not discharged prior to acquisition of the collateral by the seller. ${ }^{54} B$ may also be subject to the perfected security interest of a greedy creditor of the seller whose interest attaches to any and all goods acquired for any and all purposes. But if the "financing" buyer's security interest is perfected simultaneously with attachment, complete protection is obtained against the following risks: (1) a creditor whose security interest in the same collateral attached first but has not been perfected; (2) a subsequent lien creditor with or without actual notice; (3) a prior creditor with a perfected security interest in the same collateral if the "financing" buyer obtains a "purchase" money security interest, has it perfected at the time the debtor obtains possession of the collateral; and gives a prescribed notice; and (4) if the "financing" buyer has a "purchase" money security interest, any creditor who has subsequently perfected any type of security interest. ${ }^{55}$ Again, the importance

52 U.C.C. § 9-301 (1); Cax. Comm. Code § 9301(1). See U.C.C. § 9-201; CaL. Coram. CODE $\S 9201$.

53 See Ibid. The holder of any purchase money security interest who files within ten days after the collateral comes into possession of the debtor takes priority over a transferee in bulk or a lien creditor whose rights have arisen between the time the security interest attached and the time of filing. U.C.C. $\$ 9-301(2)$; CaL. CoMra. CODE \$ 9301(2). Cf. diṣcussion in note 51 supra. Since a "ken" creditor is "a creditor who has acquired a ben on the property involved by attachment, levy or the like," U.C.C. § 9-301 (3); CAT. CoMas. CodE $\S 9301(3)$, the ten day rule does not protect the unperfected purchase money security interest in inventory if another creditor first perfects a security interest in the same collateral.

54 This risk is minimal. Even if a third person has perfected a security imterest in goods purchased by the seller for use in manufacturing, if the seller purchases in the ordinary course of business he "takes free of a security interest created by his seller even though the security interest is perfected and even though the buyer knows of its existence." U.C.C. § 9-307(1); CAL. CoMMM. Code § 9307(1).

55 See U.C.C. § 9-312; CAL. CoMm. Code § 9312.

How effective is the government's "title" to progress payment inventory against other creditors of or purchasers from the contractor? It should he remembered that the government must ohtain "adequate" security, that adequate security may be a hen on property acquired 
of the "purchase" money security interest, here for priority purposes, should be noticed.

What about purchasers of the collateral? The "financing" buyer is protected against a purchaser for value not in the ordinary course of business with or without notice. ${ }^{56}$ Any sales of raw materials or work in process before the goods are completed would probably not be in ordinary course and thus subject to the security interest. But if the heaters are completed and are sold in the ordinary course of business, the buyer may take free of the perfected security interest. Regardless of actual notice, the buyer in the ordinary course of business will be protected if the seller holds the inventory for sale at retail to any purchaser. ${ }^{57}$ In our problem, however,

for performance and the resulting lien is paramount. 10 U.S.C. $\$ 2307$ (1958). If title is treated literally and the government is considered an owner of property in the contractor's possession an "entrusting" situation exists. Despite this, once title vests in the United States the property is immune from subsequent liens asserted by creditors of the contractor. See Armstrong v. United States, 364 U.S. 40 (1960) (United States subject to mechanics lien attaching to -property before title vests). It would also seem that a contractor in possession of government owned property cannot pass good title to a purchaser for value without notice. Shephard Eng'r Co. v. United States, 287 F.2d 737, rehearing denied, 289 F.2d 681 (8th Cir. 1961) (remedy of replevin used agaimst third person; doctrine of estoppel does not apply against United States). Thus, ownership by the United States provides complete protection. The. United States is entitled to possession against the contractor and all third persons asserting claims subsequent to the vesting of title.

In view of 10 U.S.C. $\$ 2307$ (1958), however, if the government simply created a hen in the described inventory to secure progress payments, that lien would be paramonnt. In this section Congress has established a federal rule requiring security and determining its priority. While other private interests may attach subject to the government's priority, Armstrong v. United States, supra, the United States security interest is paramount without regard to the perfection requirements of state law. See, e.g., United States v. County of Allegheny, 322 U.S. 174 (1944); Clcarfield Trust Co. v. United States, 318 U.S. 363 (1943); United States v. Lennox Metal Mfg. Co., 225 F.2d 302 (2d Cir. 1955). In the absence of a clear congressional statement of priority, the United States may as a matter of federal law be required to perfect a security interest under the law of the state where the transaction took place. See Bumb v. United States, 276 F.2d 729 (9th Cir. 1960).

56 A buyer in the ordinary course of business is "a person who in good faith and without knowledge that the sale to him is in violation of the ownership rights or security interest of a third party in the goods buys in ordinary course fronl a person in the business of selling goods of that kind ..." U.C.C. $\$ 1-201(9)$; CAE. COMnM. CODE $\$ 1201(9)$. While an nnperfected security interest is subject to the riglits of any buyer who gives value without knowledge of the security interest, perfection gives the creditor priority over any buyer not in the ordinary course of business. Cf. U.C.C. $\$ \$ 9-312(1), 9-307$ (1); Cax. Comar. CodE $\$ \$ 9312(1), 9307$ (1). This follows even though the buyer gives value and has no actual knowledge.

57 U.C.C. $\$ 9-307$ (1); CAI. COASMr. CODE $\$ 9307$ (1). Normally, the holder of a security interest in inventory collateral expects and encourages the debtor to sell in the ordinary course of busmess. Since the perfected security interest will continue in the proceeds of sale, the creditor does not lose his security simply because the purchaser takes free of the security interest. But goods to be manufactured for the "financing" buyer are not intended for sale to third persons even though the manufacturer sells goods of that kind at retail. Thus, a potential conflict between the "financing" buyer's and the purchaser's interest in the goods exists. 
the seller holds the goods completed for sale to the "financing" buyer. While a sale in the ordinary course of business to a third party may still occur, that sale is a breach of the contract for sale with $B$. This breach, however, will not alter the third party purchaser's rights unless the security agreement expressly prohibits the sale and the buyer in the ordinary course has actual knowledge of the restriction. ${ }^{58}$ And in any event, if the financing statement so provides the security interest continues in any proceeds derived from a sale in the ordinary course of business. ${ }^{69}$ While the proceeds security may be lost by commingling or dissipation, these risks can be reduced by careful policing and supervision by the "financing" buyer.

\section{Remedies Available Upon Default}

If our non-possessory purchase money security interest in inventory collateral has been created and perfected under article 9, what remedies are available to the "financing" buyer upon default by the seller? With exceptions not applicable here, the "financing" buyer has rights and remedies provided either in part 5 of article 9 or in the security agreement. In general, the "financing" buyer as a creditor will be able to levy on or take possession of the collateral and by disposition or retention liquidate the obligation secured.

In the absence of any agreed remedies, two basic statutory alternatives exist. First, $B$ may reduce his claim to judgment and "foreclose or otherwise enforce the security interest by any available judicial procedure." The lien of any levy resulting from the judgment relates back to the date when the security interest was perfected. Second, $B$ unay take possession of the collateral either with or without judicial process if the latter "can be done without breach of the peace ...." The collateral taken may be sold, leased, or otherwise disposed of and the proceeds applied to satisfy the indebtedness secured. Any sale of collateral following the taking of

58 Arguably a buyer of goods is not in "good faith," see note 56 sucpra, when he purchases with actual knowledge that the seller has not been authorized to sell the goods. While knowledge of the security interest alone will not preclude a valid sale, knowledge of a restriction on the seller's power to sell will. See U.C.C. § 9-306(2); CAL. CoMmr. CodE § 9306(2).

59 If the goods have not been completed at the time of sale it is more difficult to show that the sale was in the ordinary course of business. If the goods have been completed and the seller is in the business of selling goods of that kind, a buyer in the ordinary course of business without actual knowledge of a restriction of the seller's apparent authority to sell will be protected. See notes 56-58 supra. Despite this, the "financing" buyer's security interest "continues in any identifiable proceeds," here cash procecds from the sale. U.C.C. \$9-306(1)-(2); CAL. COMMM. CODE $\$ 9306(1)-(2)$. To insure continuous perfection the "financing" buyer should file a financing statement covering the originally described collateral and proceeds. U.C.C. \$9-306(3) (a); CAL. CoMnr. CODE \$ 9306(3) (a).

60 U.C.C. $\$ 9-501$ (1); CaI. CoMar. Code $\$ 9501$ (1).

61 U.C.C. § 9-503; CaI. Comms. Code § 9503. 
possession is subject to article $2{ }^{62}$ If provided in the security agreement, taking possession upon default may be facilitated by requiring the debtor to assemble the collateral and make it available to the secured party at a place to be designated by the secured party which is reasonably convenient to both parties. ${ }^{\text {3 }}$

Suppose, however, upon taking possession, the "financing" buyer decides not to "sell, lease or otherwise dispose" of the collateral, but instead to accept and retain the collateral in full discharge of the obligation. ${ }^{\text {et }}$ The "financing" buyer-creditor must then send a written notice of this intention to the seller-debtor and any other party who has a perfected security interest in the collateral filed in the state or is known to have a security interest. If no objection in writing is received within 30 days of the receipt of notification, the creditor may retain the collateral in satisfaction of the debtor's obligation. If, however, timely objection is received in writing from either the debtor or other secured parties notified, the "financing" buyer must dispose of the collateral..$^{05}$

Furthermore, aside from the "notice-objection" procedure, the debtor has a right to redeem the collateral..$^{66}$ On our facts, however, it is unlikely that redeinption would be used, since the debtor, as a seller of goods, will have little desire in most cases to repay the advance in order to recover goods or work in process specially manufactured for the buyer-creditor. Any remaining risk here can be removed by an agreement in writing after default that the collateral will not be redeemed.67

The practical and legal results are these. If no objection is received, retention of the collateral discharges the obligation including any claim for deficiency. If objection is made, the collateral must be disposed of and an accounting made. The right to object is one which cannot be waived or varied by agreement under part 5 of article $9 .{ }^{68}$

62 U.C.C. \$ 9-504; CAL. COMOM. CODE \$ 9504. "If the security interest secures an indebtedness, the secured party inust account to the debtor for any surplus, and, unless otherwise agreed, the debtor is liable for any deficiency." U.C.C. \$ 9-504(2); CAL. Comm. CodE § 9504(2).

63 See U.C.C. § 9-503; CAL. Conar. Code § 9503.

04 U.C.C. $\$ 9-505(2)$; CAL. CoMn. CodE $\$ 9505(2)$.

05 Ibid. The disposition is governed by U.C.C. \$ 9-504; CaL. Comm. CodE \$ 9504. Compulsory disposition of the collateral where the debtor has paid $60 \%$ of the cash price in the case of a purchase money security interest and $60 \%$ of the loan in other transactions is limited to collateral classified as consumer goods. U.C.C. $\$ 9-505(1)$. There is no comparable provision in the California Commercial Code.

00 U.C.C. § 9-506; CaI. Conam. Code \$ 9506.

67 U.C.C. \$ 9-501(3); Cal. Comm. Code \$ 9501(3). See U.C.C. \$ 9-506; CaL. Comm. CODE $\S 9506$.

68 U.C.C. \$ 9-501(3) (c); CaL. Commr. Code \$ 9503(3) (c). See Hogan, The Secured Party and Defantt Proceedings under the UCC, 47 MnNN. L. REv. 205 (1962).

The contractual remedies available to the government upon default by a contractor receiving progress payments are marvels of efficiency. They arise from a combination of 


\section{CONCLUSION}

No attempt has been made in this brief discussion to treat exhaustively the position of the "financing" buyer under the Uniform Commercial Code. Nor does this article purport to express in definitive form all of the terms and conditions that might be included in the written security agreement. The intention has been to expose some fundamental problems and suggest a basic planning approach when the client, in a single transaction, is both a purchaser of goods and a creditor. Effective protection is achieved only if the attorney has a thorough understanding of the strengths and weaknesses of Articles 2 and 9 of the Uniform Commercial Code. But regardless of which interest is involved, that of purchaser or of creditor, the "financing" buyer is best protected when he is able to take physical possession of the described goods upon default by the seller.

Under article 2, possessory remedies in effect accomplish specific performance of the contract for sale. The buyer takes the goods as an owner pursuant to agreement. He then becomes obligated to pay the price and in this way previous advances against delivery are liquidated. But in essence the availability of possessory remedies depends upon the scope of the "special property" interests created upon identification. Before identification there is no right to take possession. After identification the buyer's possessory remedies depend upon insolvency in limited cases or general market non-availability. These limitations are further restricted by potential claims of creditors and buyers in the ordinary course of business. And it is clear that the parties cannot by agreement expand the scope of the special property interest against these third parties without complying with article 9. Thus, if the "financing" buyer's sole interest is obtaining goods which satisfy his needs and desires as a potential owner, the reme-

the progress payment clause, 32 C.F.R. $\$ 163.79-1$ (c), (h) (1961), and the termination for default clause, standard form 32, clause 11, 41 C.F.R. §1-16.901-32(11) (1963). Short of a default by the contractor which justifies termination of the contract, the contracting officer may under six specific circumstances reduce or suspend progress payments or hiquidate them at a percentage higher than $70 \%$. For example, suspension of progress payments would be proper if the contracting officer found substantial evidence that the contractor "has so failed to make progress . . . as to endanger performance" of the contract or has "allocated inventory to this contract substantially exceeding reasonable requirements . . ." 32 C.F.R. \$ 163.79-1(c) (1961). If the contractor fails to meet the contract delivery schedule and the contract is terminated for default, the contractor may be required to "transfer title and deliver to the Government, in the manner and to the extent directed by the Contracting Officer, (i) any completed supphes, and (ii) such partially completed supphes and materials, parts, tools, dies, jigs, fixtures ... (hereinafter called 'manufacturing materials') as the Contractor has specifically produced or specifically acquired for the performance of such part of this contract as has been termmated." 41 C.F.R. $\$ 1-16.901-32$ (11) (1963). In addition, upon a default termination the contractor, upon demand, shall pay to the government the amount of unliquidated progress payments. 
dies of article 2 upon breach by the seller are fairly adequate. If the same or similar goods cannot be purchased from alternative sources with reasonable efforts the possessory remedies are available. In either case the buyer's needs are satisfied. But if the "financing" buyer is also interested in securing the obligation of a breaching seller to repay advances, the possessory remedies of article 2 provide tenuous protection. If the contracted goods can reasonably be obtained froin alternative sources, the obligation of the seller to repay the advance is unsecured.

Under article 9, possessory remedies are readily available to a creditor upon default by a debtor if a security interest in described collateral has been created and perfected. In the case of the "financing" buyer, the strengths of article 9 more than compensate for the remedial weaknesses in article 2. A security interest may be created and perfected in described collateral at the moment of acquisition by the debtor and continue through the manufacturing process into the completed item. Upon default by the seller, the "financing" buyer has possessory rights against the seller, the seller's creditors, and purchasers for value not in the ordinary course of business. As a result, the obligation to repay the advance is liquidated and discharged as the "financing" buyer disposes of or retains the collateral in accordance with part 5 of article 9. It would seein, then, that a careful and planned combination of articles 2 and 9 will generally produce realistic and complete protection for the buyer of goods who las made advances to the seller prior to delivery.

Despite this, a vague feeling of discomfort remains. The "financing" buyer's transaction involves dual, overlapping interests which do not fit cleanly into the pattern of articles 2 and 9. While the "special property" interest acquired upon identification of goods to a contract for sale may indirectly achieve security results by supporting possessory remnedies under article 2, it seems clear under the Code that a definite line-a functional line-is drawn between the concepts of "special property" and "security interest." Article 2 is prinarily devoted to insuring performance of the contract for sale and this, of course, is the primary goal of the "financing" buyer. Article 9 is seemingly exclusively devoted to securing the perfornance of obligations or payment of debts. Yet the "financing" buyer lias advanced money to facilitate the seller's performance of the contract. The advance is not due until the seller breaches the primary obligation to detiver goods. In a real sense, then, what the "financing" buyer has secured under article 9 is the seller's duty to repay the advance upon breach of the primary obligation to deliver goods. Article 9 and its function becomes important only when the remedies of article 2 are found lacking and then is seemingly applied to an obligation not clearly provided for in the definition of security interest. Nonetheless, the "financing" buyer should receive 
the same protection as a third party creditor who lends the seller money to facilitate contract performance and creates a purchase money security interest in the work in process. A functional approach does much to relieve definitional discomforts, particularly where, as here, the advance financing transaction has considerable busmess utility.

Some problems remain, however. Suppose in our problem that after the "financing" buyer has created and perfected the security interest in manufacturing inventory and advanced 4,000 dollars against the contract price, the seller breaches the contract by repudiation. The reason is financial inability. In the seller's possession is a large quantity of work in process allocated to contract performance and ten units which have been completed but not identified to the contract. There is one other creditor with a perfected but junior security interest in the same collateral. Under our analysis, the buyer has no right to possession under article 2 until the goods have been identified to the contract. To satisfy his interest as a purchaser, the buyer must enter into a new contract for manufacture and sale with another producer and is relegated, without more, to unsecured remedies under article 2 for breach of contract. Under article 9, however, the buyer may take possession of this collateral to satisfy the obligation of the seller to repay advances made. But does the "financing" buyer take this collateral exclusively as a creditor rather than a purchaser? The apparent conclusion under article 9 is that he does. Is it realistic to assume that the "financing" buyer will not be interested in taking the collateral as an owner simply because possessory remedies are not available under article 2 ? The obvious answer to this question is no. The work in process and completed umits may have considerable utility in the repurchase contract or as salvaged inventory. An important question, therefore, is whether a "financing" buyer with a perfected security interest in inventory has any option to use the security interest to obtain permanent possesion of the collateral and, if so, how effective is this option?

As we have seen, under Uniform Commercial Code 9-505(2), a creditor who has taken possession after default by the debtor may elect to retain the collateral in satisfaction of the secured obligation. He retains possession as an owner and the practical result is a "sale" in which the creditor foregoes any claim to the difference, if any, between the amount advanced and the value of the collateral. But to implement this election the creditor must notify the debtor and certain other creditors with perfected security interests in the same collateral. If these notified parties object in writing the creditor must dispose of the collateral. Presumably objection will occur in cases where the value of the collateral exceeds the amount of the loan and, in this way, an accounting is compelled. Finally, the "notice-objection" procedure cannot be varied by agreement between 
the creditor and the debtor. Thus, while the "financing" buyer has an option to use the security interest as a method to obtain permament possession and use, the option has some definite and potentially disruptive restrictions.

This analysis reveals an unwarranted functional rigidity. The "noticeobjection" procedure may deprive the "financing" buyer of an option to retain the collateral as an owner without inquiring whether retention has in fact impaired legitimate interests of the debtor and other secured creditors. Assuming that the purpose of "notice-objection" is to insure that the creditor will not retain collateral, the value of which exceeds the loan amount, the same protection can be achieved without subjecting the "financing" buyer to the risk of losing possession. If the option to retain possession is exercised, the "financing" buyer should be contractually obhgated to pay the contract price for all completed units and the reasonable value of any work in process. The total amount due for inventory delivered should be offset against the total advances made and any excess paid to the seller, subject, of course, to further deductions for breach of contract damages. The fixed contract price will provide a ceiling on the "financing" buyer's liability and if the advances are fairly geared to the seller's progress no great disparity between advances made and work done should arise. Simce the parties are not free under the present version of the Code to accomplish this by agreenient, an amendment to section 9-505(2) permitting the "financing" buyer to retain possession without the "notice-objection" procedure but requiring an accounting as suggested above seems advisable. This result would preserve the purpose of the "notice-objection" procedure and, at the same tinie, give a more realistic, flexible remedy to the "financing" buyer. If the buyer has in fact made advances and if a security interest has in fact been created and perfected in inventory to be manufactured for sale to the buyer, neither the seller nor third parties can legitimately complain if the security interest is in fact used to expand possessory remedies to achieve article 2 results. While the "financing" buyer's right to possession is derived from article 9, its notivation and the resulting incidents of ownership are more consistent with a sale than simple security. Other junior creditors must rely on a continuing security interest in proceeds derived from the retention procedure and paid to the seller. 